\title{
The Relationship Between Life Satisfaction of the School of Physical Education and Sports Students and Their Levels of Sports Engagement
}

\author{
Hande İnan \\ School of Physical Education and Sports, Adıyaman University, Adıyaman, Turkey \\ Tel: 90-535-631-5818Ｅ-mail: hinan@adiyaman.edu.tr
}

Mine Koç (Corresponding author)

Adiyaman Provincial Directorate of Youth and Sports, Adiyaman, Turkey

Tel: 90-505-624-0626_E-mail: minekoc0683@gmail.com

Received: June 17, 2021 Accepted: July 26, $2021 \quad$ Published: August 2, 2021

doi:10.5296/jei.v7i2.18756 URL: https://doi.org/10.5296/jei.v7i2.18756

\begin{abstract}
This study aims to investigate the correlations between the life satisfaction of students of study sport sciences and their levels of sports engagement according to a number of variables. The study group was composed of 116 undergraduate students attending the School of Physical Education and Sport of Adiyaman University.

The participants were administered "Sports Engagement Scale (SES)" and "Satisfaction with Life Scale (SWLS)" in addition to a personal information form prepared by the researcher. The data collected were analysed on SPSS statistics programme and 0.01-0.05 significance level was accepted for the statistical validity of the data.

Weak and positive correlations were found between physical education and sport school students' life satisfaction with life and their sports engagement. In addition to that, weak and negative correlations were found between the participants' grade point averages and their scores of sports engagement. The female students' grade point averages were significantly higher than the male students'.

In conclusion, university students' sports engagement results in more satisfaction with life. The increase in sports engagement and life satisfaction of university students causes a decrease in their academic success.
\end{abstract}


Keywords: Sports engagement, Life satisfaction, Sport sciences

\section{Introduction}

University students prepare for the future intensely today during their education. Leading a happy, meaningful and satisfactory life away from worries in the process helps them to make their life easier, to get satisfaction from life and to make sports engagement a lifestyle.

The major element that individuals should have in order to be happy in life is life satisfaction. It has been a focus of humans' interest for centuries. "Life Satisfaction is a cognitive component of wellbeing and it involves cognitive judgements about individuals' lives (Diener et al., 1985)". The term subjective wellbeing is usually referred to as happiness in the literature of positive psychology (Diener, 2000).

Life Satisfaction expresses the state of wellbeing in terms of happiness and morale and the dominance of positive feelings over negative ones in daily routine (Vara, 1999). It is defined as an individual's positive evaluation of all his/her life in accordance with the criteria he/she has set (Diener et al., 1985).

Life Satisfaction which involves the whole life, is an important indicator of an individual's psychological health. Various impediments, hardships, conflicts and sudden negative changes individuals encounter in life can diminish their life satisfaction (Demirel \& Canat, 2001).

Individuals' life satisfaction is influenced by various factors. Some of them can be listed as happiness felt in daily life, meaning assigned to life, consistency in attaining goals, positive personal identity, feeling physically well and economic, safe and social relations (Schmitter, 2003; Y1lmaz \& Arslan, 2013).

Sport has today become an integral part of social life. Social activities and the approach of certain branches of sport tend to be higher today in terms of feeling close to oneself. However, individuals inclination towards a branch of sport is determined by their interest in curiosity about the branch and their ability in the sport which they feel close to them (Tükenmez, 2009). Young population in the society incline towards sport so as to spend time well and to develop their social circle in addition to developing physically and improving their skills; and thus, they develop in terms of character and they learn to take on responsibilities (Koç, 2005). Adults, just like young people, orientate towards sport in order to lead a healthy life and to develop their social life, but the factor of improving the skills becomes of secondary importance, and even is not considered very important (Roberts, 2012).

Adherence is defined as the positive state which arises with vigour, absorption and dedication (Schaufeli et al., 2002). Vigour is an individual's ability to display his or her best performance and to struggle with obstacles without fearlessly. Absorption means focussing on the work done, adopting the branch of sport done and concentrating on it and not being distracted by anything else. Dedication is described as an individual's enjoyment of what he or she does, his or her considering his or her branch of sport prior to everything and assigning different meanings to his or her world (Gulien \& Alvarado, 2012). Athletes' adherence is described as their self-confidence, efforts, states of mobility and being completely within 
sport and having positive mental state (Lonsdale et al., 2007).

There are direct correlations between falls in students' physical activities and in their participation in sport, their pleasure with life and diminishing in their personal health (Zullig \& White, 2011).

There are social and sport environments in which students at university can spend their leisure time effectively and do activities increasing their satisfaction with life and adherence to sport. Therefore, this study aims to associate the life satisfaction of students attending faculties of sports sciences with adherence to sport. On examining the relevant national and international literature, mostly studies which considered sports engagement and life satisfaction separately were found but the number of studies considering the two together were found to be limited. Thus, the current study is thought to contribute to and guide the future studies.

\section{Method}

\subsection{Research Model}

This study, which analyses the satisfaction with life of students studying sport and their adherence to sport, is a descriptive study and it uses the survey model. The conditions of the individuals, subjects, events and objects considered are described and reported as they are in a survey model (Arlı \& Nazik, 2001). The model makes efforts to describe the tendencies, attitudes or views of an appropriate sample representing the population by transforming them into quantitative or numerical data (Fowler, 2008).

\subsection{The Study Group}

Totally 116 undergraduate students attending the School of Physical Education and Sport of Adiyaman University in 2020-2021 academic year-57 of whom were female and 59 of whom were male-were included in this study.

Table1. Participants' descriptive statistics on demographic variables

\begin{tabular}{|l|l|l|l|l|l|}
\hline Gender & $\mathbf{n}$ & $\mathbf{\%}$ & Branches of sport & $\mathbf{n}$ & $\mathbf{\%}$ \\
\hline Female & 57 & 49.1 & Individual sport & 50 & 43.1 \\
\hline Male & 59 & 50.9 & Team sport & 66 & 56.9 \\
\hline Levels of academic achievement & $\mathbf{n}$ & $\mathbf{\%}$ & Body-mass index (BMI) & $\mathbf{n}$ & $\mathbf{\%}$ \\
\hline Weak & 10 & 8.6 & Weak & 13 & 11.2 \\
\hline Medium & 49 & 42.2 & Normal weight & 81 & 69.8 \\
\hline Good & 48 & 41.4 & Overweight (fat) & 22 & 19.0 \\
\hline Very good & 9 & 7.8 & Total & 116 & 100 \\
\hline
\end{tabular}


As seen in Table $1,49.1 \%$ of the participants were female whereas $50.9 \%$ were male most of whom $(68.1 \%)$ were at medium level of academic achievement and very few of whom $(7.8 \%)$ were at low level of academic achievement.

\subsection{Data Collection Tools}

The participants were administered "Sports Engagement Scale (SES)" and "Satisfaction with Life Scale (SWLS)" in addition to a personal information form prepared by the researcher.

\subsubsection{The Sport Engagement Scale}

The Spanish version of the Utrecht Work Engagement Scale (UWES) developed by Schaufeli et al. (2002) was adapted for athletes by Guillen and Alvarado (2012), and its Turkish adaptation "The sport engagement scale (SES), made by Sirganc1 et al. (2019) was used in this study. The sport engagement scale (SES) is a 5-pointed Likert type scale with 15 items and 3 sub-factors labelled as vigor, absorption and dedication (Sirganc1 et al., 2019).

\subsubsection{Satisfaction with Life Scale}

To measure life satisfaction, we used the Satisfaction with Life Scale (SWLS) by Diener et al. (1985) and which was adapted into Turkish by Dağlı and Baysal (2016), was given to the participants online. The scale is a one-factor, 5-item measurement instrument. It is a 5-pointed Likert type scale with 5 questions which determines individuals' perceptions of their living conditions and their satisfaction with life.

\subsection{Data Analysis}

The SPSS 26.0 package program was used in the analysis of the data and the frequency, arithmetic average, standard deviation, and percentage values of the collected data were calculated. The parametric oneway anova test anda independent-samples $t$ test was used to assess the significance of differences between the variables, and the correlations between the variables were calculated using pearsons's rank correlation coefficient. Effects for which the probability was lower than the level of statistical significance of $p<0.05$ and $p<0.01$ were assumed as significant. 


\section{Results}

Table 2. Participants' descriptive statistics on measurement parameters

\begin{tabular}{|l|l|l|l|l|l|}
\hline Variables & $\mathbf{n}$ & Min & Max & $\overline{\mathbf{x}}$ & Sd \\
\hline Age (year) & 116 & 18 & 35 & 21.93 & 2.434 \\
\hline Height $(\mathrm{cm})$ & 116 & 156 & 191 & 173 & .07780 \\
\hline Weight $(\mathrm{kg})$ & 116 & 45 & 106 & 66.36 & 12.699 \\
\hline Body-mass index $\left(\mathrm{kg} / \mathrm{m}^{2}\right)$ & 116 & 16.61 & 29.36 & 22.06 & 2.89676 \\
\hline Grade point average & 116 & 1.35 & 3.67 & 2.86 & .43758 \\
\hline The satisfaction with life scale & 116 & 1.00 & 5.00 & 3.05 & 1.00749 \\
\hline The sports engagement scale & 116 & 1.00 & 5.00 & 3.86 & .80786 \\
\hline Factor of vigor & 116 & 1.00 & 5.00 & 3.74 & .83131 \\
\hline Factor of dedication & 116 & 1.00 & 5.00 & 3.98 & .88746 \\
\hline Factor of absorption & 116 & 1.00 & 5.00 & 3.88 & .86957 \\
\hline
\end{tabular}

The average for participants age was $\bar{x}=21.93$, their grade point average was $\bar{x}=2.86$, the average for satisfaction with life was $\bar{x}=3.05$, the average for sports engagement was $\bar{x}=$ 3.86 and the average for BMI was $\overline{\mathrm{x}}=22.06$. 
Table 3. Correlation analysis results for relationship between grade points averages, BMI, life satisfaction, sports engagement and age

\begin{tabular}{|c|c|c|c|c|c|c|c|c|}
\hline \multicolumn{2}{|l|}{$\begin{array}{l}\text { Variables } \\
(\mathrm{n}=116)\end{array}$} & $\begin{array}{l}\text { Grade point } \\
\text { averages }\end{array}$ & $\begin{array}{l}\text { Life } \\
\text { Satisfaction }\end{array}$ & $\begin{array}{l}\text { Sports } \\
\text { Engagement }\end{array}$ & Vigor & Dedication & Absorption & BMI \\
\hline \multirow{2}{*}{ Grade point average } & $\mathbf{r}$ & 1 & -.174 & $-.191^{*}$ & $-.250^{* *}$ & $-.185^{*}$ & -.106 & -.141 \\
\hline & $\mathbf{p}$ & & .062 & .040 & .007 & .047 & .257 & .132 \\
\hline \multirow{2}{*}{ Life Satisfaction } & $\mathbf{r}$ & -.174 & 1 & $.291^{* *}$ & $.296^{* *}$ & $.288^{* *}$ & $.235^{*}$ & .026 \\
\hline & p & .062 & & .002 & .001 & .002 & .011 & .780 \\
\hline \multirow{2}{*}{ Sports Engagement } & $\mathbf{r}$ & $-.191^{*}$ & $.291^{* *}$ & 1 & $.922^{* *}$ & $.958^{* *}$ & $.928^{* *}$ & .016 \\
\hline & $\mathbf{p}$ & .040 & .002 & & .000 & .000 & .000 & .864 \\
\hline \multirow{2}{*}{ Vigor } & $\mathbf{r}$ & $-.250^{* *}$ & $.296^{* *}$ & $.922^{* *}$ & 1 & $.841^{* *}$ & $.756^{* *}$ & .037 \\
\hline & $\mathbf{p}$ & .007 & .001 & .000 & & .000 & .000 & .691 \\
\hline \multirow{2}{*}{ Dedication } & $\mathbf{r}$ & $-.185^{*}$ & $.288^{* *}$ & $.958^{* *}$ & $.841^{* *}$ & 1 & $.845^{* *}$ & -.024 \\
\hline & $\mathbf{p}$ & .047 & .002 & .000 & .000 & & .000 & .799 \\
\hline \multirow{2}{*}{ Absorption } & $\mathbf{r}$ & -.106 & $.235^{*}$ & $.928^{* *}$ & $.756^{* *}$ & $.845^{* *}$ & 1 & .034 \\
\hline & p & .257 & .011 & .000 & .000 & .000 & & .721 \\
\hline \multirow{2}{*}{ BMI } & $\mathbf{r}$ & -.141 & .026 & .016 & .037 & -.024 & .034 & 1 \\
\hline & $\mathbf{p}$ & .132 & .780 & .864 & .691 & .799 & .721 & \\
\hline \multirow{2}{*}{ Age } & $\mathbf{r}$ & .067 & .165 & -.072 & -.079 & -.067 & -.058 & $.443^{* *}$ \\
\hline & $\mathbf{p}$ & .474 & .078 & .441 & .402 & .476 & .535 & .000 \\
\hline
\end{tabular}

Note. ${ }^{* *}$ Correlation is significant at the 0.01 level (2-tailed).

As a result of Pearson's correlation test which was done to check the correlations between participants' satisfaction with life and sports engagement scale scores, the findings obtained were as in the following:

Positive and medium correlations were found between the scores received from sports engagement $(r=.291 ; \mathrm{p}=.002<0.01)$ and from the sub-factors of dedication $(\mathrm{r}=.288 ; .002<$ $0.01)$ and absorption $(r=.235 ; \mathrm{p}=.011<0.05)$. Synchronic rises and falls occurred in the participants' levels of satisfaction with life and sports engagement.

The students' ages and body-mass index scores $(r=.443 \mathrm{p}=.000<0.01)$ were found to have positive and medium correlations. Thus, it can be said that their body-mass index increases as their age rises- in other words, they put on weight as they age.

The correlation analysis demonstrated that there were no significant correlations between grade point averages and satisfaction with life averages $(\mathrm{p}>0.01)$.

Negative and medium correlations were found between scores received from sports 


\section{Macrothink}

Journal of Educational Issues

ISSN 2377-2263 2021, Vol. 7, No. 2

engagement $(r=-.191 ; p=.04<0.05)$ and from the sub-factors of vigor $(r=-.250 ; p=.00<$ $0.05)$ and dedication $(\mathrm{r}=-.185 ; \mathrm{p}=.047<0.05)$. The students' grade point averages fell while their levels of sports engagement.

Table 4. Independent T-Test results on students' grade point averages according to the gender and branch of sport variable

\begin{tabular}{|l|l|l|l|l|l|}
\hline Variables & $\mathbf{n}$ & $\overline{\mathbf{x}}$ & Sd & $\mathbf{t}$ & P \\
\cline { 1 - 5 } Female & 57 & 2.96 & .33112 & \multirow{2}{*}{2.628} & \multirow{2}{*}{$.009^{*}$} \\
\cline { 1 - 5 } Male & 59 & 2.76 & .50210 & & \\
\cline { 1 - 4 } Individual sports & 50 & 2.72 & .52855 & \multirow{2}{*}{-3.150} & \multirow{2}{*}{$.004^{*}$} \\
\cline { 1 - 4 } Team sports & 66 & 2.97 & .31786 & & \\
\hline
\end{tabular}

Note. ${ }^{*} p<0.01$.

As clear from Table 4, significant differences were found between participants' grade point averages according to gender $(\mathrm{t}=2.628 ; \mathrm{p}=0.009<0.01)$. Accordingly, the female students had higher grade point average $(\bar{x}=2.96)$ than the male ones $(\bar{x}=2.76)$. Statistically significant differences were found between the participants' grade point averages according to their branch of sport $(\mathrm{t}=-3.150 ; \mathrm{p}=0.004<0.01)$. Thus, the students who did team sports had higher averages $(\bar{x}=2.97)$ than those who did individual sports $(\bar{x}=2.72)$. 
Table 5. ANOVA results regarding the life satisfaction and sports engagement according to classification academic achievement

\begin{tabular}{|c|c|c|c|c|c|c|}
\hline Variables & Academic achievement & $\mathbf{n}$ & $\overline{\mathbf{x}}$ & Sd & $\mathbf{F}$ & $\mathbf{P}$ \\
\hline \multirow{4}{*}{ Life Satisfaction } & Weak & 10 & 3.44 & .96977 & \multirow{4}{*}{2.86} & \multirow{4}{*}{.073} \\
\hline & Medium & 49 & 3.17 & 1.07005 & & \\
\hline & Good & 48 & 2.78 & .92183 & & \\
\hline & Very Good & 9 & 3.42 & .89132 & & \\
\hline \multirow{4}{*}{ Sports engagement } & Weak & 10 & 4.29 & .95584 & \multirow{4}{*}{1.149} & \multirow{4}{*}{.332} \\
\hline & Medium & 49 & 3.84 & .77434 & & \\
\hline & Good & 48 & 3.84 & .79020 & & \\
\hline & Very Good & 9 & 3.65 & .89863 & & \\
\hline \multirow{4}{*}{ Vigor } & Weak & 10 & 4.38 & .97274 & \multirow{4}{*}{2.437} & \multirow{4}{*}{.068} \\
\hline & Medium & 49 & 3.72 & .77655 & & \\
\hline & Good & 48 & 3.66 & .81596 & & \\
\hline & Very Good & 9 & 3.51 & .85505 & & \\
\hline \multirow{4}{*}{ Dedication } & Weak & 10 & 4.50 & 1.02089 & \multirow{4}{*}{1.576} & \multirow{4}{*}{.199} \\
\hline & Medium & 49 & 3.89 & .88512 & & \\
\hline & Good & 48 & 4.00 & .83028 & & \\
\hline & Very Good & 9 & 3.73 & .96954 & & \\
\hline \multirow{4}{*}{ Absorption } & Weak & 10 & 3.98 & .99085 & \multirow{4}{*}{.179} & \multirow{4}{*}{.910} \\
\hline & Medium & 49 & 3.91 & .87088 & & \\
\hline & Good & 48 & 3.86 & .84668 & & \\
\hline & Very Good & 9 & 3.71 & .97525 & & \\
\hline
\end{tabular}

Note. ${ }^{*} p<0.05$.

According to Table 5, the students with weak academic achievement $(\overline{\mathrm{x}}=3.44)$ were found to have the highest average and the ones with good academic achievement $(\bar{x}=2.78)$ were found to have the lowest averages on comparing their life satisfaction scores according to their academic achievement. It was also found that the students with weak academic achievement $(\bar{x}=4.29)$ had the highest averages and the ones with very good academic achievement $(\bar{x}=3.65)$ had the lowest averages on comparing their sports engagement scores according to their academic achievement. One-way variance analysis, a parametric test, was 
done so as to find whether or not the participants' life satisfaction scores differed according to their academic achievement. No significant differences were found as a result of the variance analysis $(\mathrm{p}>0.05)$.

Table 6. Independent T-Test results on life satisfaction sports engagement according to the gender variable

\begin{tabular}{|c|c|c|c|c|c|c|}
\hline Variables & Gender & $\mathbf{n}$ & $\overline{\mathbf{x}}$ & Sd & $\mathbf{t}$ & $\mathbf{P}$ \\
\hline \multirow{2}{*}{ Life Satisfaction } & Female & 57 & 3.00 & 1.1006 & \multirow{2}{*}{-.542} & \multirow{2}{*}{.589} \\
\hline & Male & 59 & 3.10 & .91529 & & \\
\hline \multirow{2}{*}{ Sports Engagement } & Female & 57 & 3.75 & .78080 & \multirow{2}{*}{-1.487} & \multirow{2}{*}{.140} \\
\hline & Male & 59 & 3.97 & .82509 & & \\
\hline \multirow{2}{*}{ Vigor } & Female & 57 & 3.55 & .76488 & \multirow{2}{*}{-2.480} & \multirow{2}{*}{$.015 *$} \\
\hline & Male & 59 & 3.92 & .85744 & & \\
\hline \multirow{2}{*}{ Dedication } & Female & 57 & 3.88 & .85352 & \multirow{2}{*}{-1.094} & \multirow{2}{*}{.276} \\
\hline & Male & 59 & 4.06 & .91760 & & \\
\hline \multirow{2}{*}{ Absorption } & Female & 57 & 3.82 & .86608 & \multirow{2}{*}{-.686} & \multirow{2}{*}{.494} \\
\hline & Male & 59 & 3.94 & .87686 & & \\
\hline
\end{tabular}

Note. ${ }^{*} p<0.05$.

It is clear from Table 6, that there are statistically significant differences between the students' scores for being fit- one of the sub-factors of sports engagement scale $(t=-2.480 ; p$ $=.015<.005)$ according to gender. Accordingly, the female students' score average for vigor $(\overline{\mathrm{x}}=3.55)$ was smaller than the male students' score average $(\overline{\mathrm{x}}=3.92)$.

No significant differences were found in the satisfaction with life Scale, the Sports Engagement Scale and in the sub-factors of dedication and absorption according to gender $(p>0.05)$. 
Table 7. Independent T-Test results on life satisfaction and sports engagement according to the Branch of sport variable

\begin{tabular}{|c|c|c|c|c|c|c|}
\hline Variables & Branches of sport & $\mathbf{n}$ & $\overline{\mathbf{x}}$ & Sd & $\mathbf{t}$ & $\mathbf{P}$ \\
\hline \multirow{2}{*}{ Life Satisfaction } & Individual Sport & 50 & 3.12 & .92317 & \multirow{2}{*}{.634} & \multirow{2}{*}{.528} \\
\hline & Team Sport & 66 & 3.00 & 1.0710 & & \\
\hline \multirow{2}{*}{ Sports Engagement } & Individual Sport & 50 & 3.98 & .75497 & \multirow{2}{*}{1.356} & \multirow{2}{*}{.178} \\
\hline & Team Sport & 66 & 3.78 & .84063 & & \\
\hline \multirow{2}{*}{ Vigor } & Individual Sport & 50 & 3.94 & .79411 & \multirow{2}{*}{2.322} & \multirow{2}{*}{$.022 *$} \\
\hline & Team Sport & 66 & 3.58 & .83191 & & \\
\hline \multirow{2}{*}{ Dedication } & Individual Sport & 50 & 4.08 & .84379 & \multirow{2}{*}{1.144} & \multirow{2}{*}{.255} \\
\hline & Team Sport & 66 & 3.89 & .91700 & & \\
\hline \multirow{2}{*}{ Absorption } & Individual Sport & 50 & 3.92 & .79591 & \multirow{2}{*}{.419} & \multirow{2}{*}{.676} \\
\hline & Team Sport & 66 & 3.85 & .92641 & & \\
\hline
\end{tabular}

Note. ${ }^{*} p<0.05 . p$ : independent sample T test.

As evident from Table 7, statistically significant differences were found between students' scores for the sub-factor of vigor $(\mathrm{t}=2.322 ; \mathrm{p}=.022<0.05)$ according to their branch of sport. Thus, the students who did team sports had lower average scores $(\bar{x}=3.58)$ than those who did individual sports $(\overline{\mathrm{x}}=3.94)$. there were no significant differences between their life satisfaction and sports engagement scores according to their branch of sport $(p>0.05)$.

\section{Discussion}

People seek life satisfaction in various activity areas, including sports. Sporting activities have a great influence on the mental and physical sense of satisfaction, enable comprehensive development, shape personality, healthy lifestyle habits, develop the will to fight, perseverance, and - at the same time - teach respect for other people (Willwéber, 2016). Sport has a large social impact, but its effects on the individual are also due to one's choice of a particular discipline. Some athletes consider sport to be the meaning of their life and thus their satisfaction with life depends on the course of their own career (Witkowski et al., 2017).

This study considered the correlations between the satisfaction with life of university students who studied sport sciences and their levels of adherence to sport.

While the participants' levels of sports engagement did not differ significantly according to gender, the male participants' scores were found to be significantly higher than the female participants' scores only in the sub-factor of being fit. 
Some of the studies in the literature (Siyahtaş et al., 2020; Yamaner et al., 2019) also found no differences in participants' levels of sports engagement according to gender- as in the case in this study. Several other studies, on the other hand, (Kelecek \& Göktürk, 2017; Francisco et al., 2017; Francisco et al., 2018; Schaufeli et al., 2002; Sivrikaya \& Biricik, 2019; Atılgan et al., 2020; Babic et al., 2015) found significant differences between participants' levels of sports engagement according to gender- contrary to the findings obtained in this study. They found that the female participants had higher sports engagement than the male participants.

Women's interest in sport has increased across the world in recent years due to the increase in opportunities for doing sport and due to legal regulations, and thus, the number of female athletes in certain branches of sport has increased. However, the increase in Turkey is not at the desired level. Women's orientation towards and active participation in sporting activities is not as easy as in the case of men due to the fact that it is a male-dominant society in Turkey. The finding that the female participants had lower sports engagement than the male participants obtained in this study can be attributed mainly to male dominance in the society.

The results of this study demonstrated that there were no differences between male and female students in terms of satisfaction with life.

Several studies concerning satisfaction with life (Bahadır, 2013; Busing \& West, 2016; Özkara et al., 2015; Telef, 2011; Tunç, 2020; Gün \& Bayraktar, 2008; Fugl-Meyer et al., 2002; Hampton \& Marshall, 2000; Hintikka, 2001; Katja et al., 2002; Wang \& Boros, 2019) found no differences between participants' levels of satisfaction with life according to gender- as in the case in this study.

On the other hand, some studies (Dost, 2007; Cenkseven \& Akbaş, 2007; Recepoğlu, 2013; Y1lmaz \& Aslan, 2013) found significant differences between participants according to gender. The diverse findings may be said to stem from the differences in the demographic properties of the sample groups.

Positive and medium correlations were found between the scores for life satisfaction and the scores for adherence to sport. In a similar way, some other studies (Olefir et al., 2019; Kilpatrick et al., 2002; Moreno et al., 2008; Moreno et al., 2017; Moraes et al., 2009; Brooks et al., 2014; Zullig \& White, 2011) also found positive correlations between satisfaction with life, exercise and physical activities.

Individuals seek life satisfaction in various areas of activities including sport. Sporting activities have large impacts on feelings of mental and physical satisfaction (Wilweber, 2016). Sport has great social effects. Some of the athletes consider sport as the meaning of their life (Witkowski et al., 2017). Besides, physical exercise is also capable of influencing life quality. It provides opportunities to satisfy the most intensive moments (Csikszentmihalyi, 1997). The finding that students' level of sports engagement is positively correlated to their life satisfaction is supported by the literature.

Positive and medium correlations were found between the participants' age and their body-mass index. Thus, it can be said that their body-mass index increases in parallel to the rise in their age- and thus, they put on weight. 
No significant differences were found in terms of sports engagement between students who did team sports and students who did individuals sports. While some of the studies in the literature found no differences between students' sports engagement according to their branch of sport (Yamaner et al., 2019), some others found differences (Siyahtaş et al., 2020; Sivrikaya \& Biricik, 2019; Kelecek \& Koruç, 2018).

Such diverse results are thought to stem from the differences in the demographic properties and branches of sports of the sample groups.

Significant differences were not available between satisfaction with life levels of students who did team sports and students who did individual sports. Several studies in the literature obtained similar findings in that satisfaction with life levels did not differ according to the types of sports (Wojdat et al., 2017; Lewandowska et al., 2017; Kuśnierz et al., 2020). The findings can be attributed to the fact that students did not have similar levels of education and or sporting background.

No significant correlations were found between the participants' age, their satisfaction with life and adherence to sport. Yet, several studies (Siyahtaş et al., 2020; Soyer et al., 2010; Johnson, 2017; Aktürk et al., 2014) found negative correlations between age and adherence to sport, unlike the finding obtained in this study. The reasons for the finding might be increase in individuals' responsibilities through time as individuals grew older, the diversification in their areas of interest and the changes in their social status. The reason for no significant correlations between age and sports engagement found in this study and in other studies (Yamaner et al., 2019; At1lgan et al., 2020; Tunç, 2020) might be that the participants were at similar ages.

Statistically significant differences were found between the participants' grade point averages according to gender and the types of sports they did. Thus, it was found that the students who did team sports attained better academic achievement than the students who did individual sports. Besides, female students were found to have better academic achievement than ale students.

This current study found no significant correlations between grade point averages and satisfaction with life. However, it found that the students who had the highest levels of satisfaction with life were the students who were weak at academic achievement and that the students who had the lowest satisfaction with life were the students who were good at academic achievement. The finding that there were no correlations between satisfaction with life and academic achievement was similar to the ones obtained in other studies (Dost, 2007; Chow, 2005).

It was found in this study that the students with very good academic achievement had the lowest sports engagement whereas the students with weak academic achievement had the highest adherence to sport. The reason for it might be that the students with weak academic achievement chose to stick to sport more and that they had interest in sport.

In conclusion, Having low academic achievement during their most intensive professional education at university can cause university students to fear that they may not graduate from 
university and to worry about losing their opportunity to receive education- which they grasped by going through difficult processes. Academic failure can be caused by such factors as dissatisfaction with their area of study, occupational indecisiveness and low motivation. Attaining academic achievement during university education- which will result in the profession that occupies most of individuals' lives and which will result in a professional identity- is one of the most important factors for their happiness.

Thus, it may be said that university students should be given more opportunities for sports and cultural activities at universities so that they can get more satisfaction with life and so that they can promote their life quality.

\section{References}

Aktürk, A. A., Özen, G., \& Üzüm, H. (2014). Amatör düzeydeki futbolcuların örgütsel bağlılıklarının incelenmesi Bolu ili örneği. International Journal of Science Culture and Sport, 1, 361-374.

Arlı, M., \& Nazik, H. (2001). Bilimsel Araştırmaya Giriş. Ankara: Gazi kitapevi.

Atılgan, D., Çilkız, M., \& Uçarer, M. Y. (2020). Çim hokeyi ve futbol branşındaki sporcuların risk değerlendirme düzeyleri ile spora bağlılıklarının incelenmesi. 18th Uluslararası Spor Bilimleri Kongresi, Kasim 07-09, 2020.

Babic, M. J., Morgan, P. J., Plotnikoff, R. C., Lonsdale, C., White, R. L., \& Lubans, D. R. (2014). Physical activity and physical selfconcept in youth: Systematic review and metaanalysis. Sports Medicine, 44(11), 1589-1601. https://doi.org/10.1007/s40279-014$0229-z$

Bahadir, Z. (2013). A research on the class management behaviors and life satisfaction of physical education teachers. International Journal of Academic Research, Part B, 5(4), 170-175. https://doi.org/10.7813/2075-4124.2013/5-4/B.25

Brooks, B. L., Mrazik, M., Barlow, K. M., McKay, C. D., Meeuwisse, W. H., \& Emery, C. A. (2014). Absence of differences between male and female adolescents with prior sport concussion. The Journal of Head Trauma Rehabilitation, 29(3), 257-264. https://doi.org/ 10.1097/HTR.0000000000000016

Busing, K., \& West, C. (2016). Determining the Relationship Between Physical Fitness, Gender, and Life Satisfaction. SAGE Open, October-December, 2016, 1-5. https://doi.org/ $10.1177 / 2158244016669974$

Cenkseven, F., \& Akbaş, T. (2007). Üniversite öğrencilerinde öznel ve psikolojik iyi olmanın yordayıcılarının incelenmesi. Türk Psikolojik Danışma ve Rehberlik Dergisi, 3(27), 43-65.

Chow, H. P. H. (2005). Life satisfaction among university students in a Canadian prairie city: A multivariate analysis. Social Indicators Research, 70, 139-150. https://doi.org/10.1007/ s11205-004-7526-0 


\section{Macrothink}

Csikszentmihalyi, M. (1997). Finding flow: The psychology of engagement with everyday life. New York, NY, US: Basic Books.

Dağl1, A., \& Baysal, N. (2016). Yaşam Doyumu Ölçeğinin Türkçe 'ye Uyarlanması: Geçerlik ve Güvenirlik Çalışması. Electronic Journal of Social Sciences, 15(59). https://doi.org/ 10.17755/esosder.263229

Demirel, S., \& Canat, S. (2001). Ankara'daki beş eğitim kurumunda kendini yaralama davranışı üzerine bir çalışma. Kriz Dergisi, 12(3), 1-9.

Diener, E. (2000). Subjective wellbeing: The science of happiness and a proposal for anational index. American Psychologist, 55(1), 3443. https://doi.org/10.1037/0003-066X.55.1.34

Diener, E., Emmons, R. A., Larsen, R. J., \& Griffin, S. (1985). The satiffaction with life scale. Journal of Personality Assessment, 49(1), 71-75. https://doi.org/10.1207/s15327752jpa 4901_13

Dost M. T. (2007). Üniversite Öğrencilerinin Yaşam Doyumunun Bazı Değişkenlere Göre İncelenmesi. Pamukkale Üniversitesi Eğitim Fakültesi Dergisi, 22(2), 132.

Fowler, F. J. (2008). Survey Research Methods. Thousand Oaks: Sage Publications.

Francisco, D. C., Arce, C., \& Grana, M. (2017). Preliminary validation of a Spanish version of the Athlete Engagement Questionnaire (AEQ). Journal of Sport Psychology, 26(4), 22-27.

Francisco, D. C., Romero, E. I. S., Arce, C., \& Conesa, P. V. (2018). The mediating role of sport self- motivation between basic psychogical needs satisfaction and athlete engagement. Psicothema, 30(4), 421-426.

Fugl-Meyer, A. R., Melin, R., \& Fugl-Meyer, K. S. (2002). Life satisfaction in 18 to 64 year old Swedes: In relation to gender, age, partner and immigrant status. Journal of Rehabilitation Medical, 34, 239-246. https://doi.org/10.1080/165019702760279242

Gullien, F., \& Alvarado, J. R. M. (2012). The Sport Engagement Scale: An Adaptation of the Utrecht Work Engagement Scale (UWES) for the Sports Environment. Universitas Psychologica, 13(2), 15-24. https://doi.org/10.11144/Javeriana.UPSY13'3.sesa

Gün, Z., \& Bayraktar, F. (2008). Türkiye'de iç göçün ergenlerin uyumundaki rolü. Türk Psikiyatri Dergisi, 19, 167-176.

Hampton, N. Z., \& Marshall, A. (2000). Culture, gender, self-efficacy and life satisfaction: A comparison between Americans and Chinese people with spinal cord injures. Journal of Rehabilation, 66(3), 21-29.

Hintikka, J. (2001). Religious attendance and life satisfaction in the Finnish general population. Journal of Psychology and Theology, 29(2), 158. https://doi.org/10.1177/0091647101029 00207 
Johnson, W. H. (2017). Sport specialization status and athlete burnout, engagement and motivation (The Masters of Sciences in Kinesiology, Sport and Exercise Psychology Option, East Carolina University).

Katja, R., Paivi, A. K., Marja-Terttu, T., \& Pekka, L. (2002). Relationships among adolescent' subjective wellbeing, health behavior and school satisfaction. Journal of School Health, 72(6), 243-250. https://doi.org/10.1111/j.1746-1561.2002.tb07337.x

Kelecek, S., \& Koruç, Z. (2017). Futbolcuların güdüsel yönelim ve spora bağlılık düzeylerinin sporcu tükenmişliğini belirlemedeki rolü. Başkent Üniversitesi Sağllk Bilimleri Fakültesi Dergisi, 2(2), 102-116.

Kilpatrick, M., Hebert, E., \& Jacobsen, D. (2002). Physical activity motivation. A practitioner's guide to self-determination theory. Journal of Physical Education, Recreation and Dance, 74(4), 36-41. https://doi.org/10.1080/07303084.2002.10607789

Koç, S. (2005). Beden Eğitimi ve Sporda Beceri Gelişimi. İstanbul: Morpa Kültür Yayınları.

Kuśnierz, C., Nowak, P. F., \& Görner, K. (2020). Determinants of life satisfaction in martial arts practitioners and team-sports players. Arch Budo, 16, 83-89.

Lewandowska, E., Kostencka, A., Dziembowska, I., \& Gotowski, R. (2017). Happiness in active and retired athletes. Stud Sportiva, 1, 265-275. https://doi.org/10.5817/StS2017-1-43

Lonsdale, C., Hodge, K., \& Jackson, S. A. (2007). Athlete engagement: 11. development and initial validation of the athlete engagement questionnaire. International Journal of Sport Psychology, 38, 471-492. https://doi.org/10.1037/t50268-000

Moraes, M., Corte-Real, N., Dias, C., \& Fonseca, A. M. (2009). Satisfac, ao com a vida, exercício físico e consumo de tabaco em adolescentes de diferentes áreas geográficas de Portugal. Revista Brasilena de Ciencias del Deporte, 30(2), 137-149.

Moreno, J. A., González-Cutre, D., \& Cervello, E. (2008). Motivación y salud en la práctica físico deportiva: Diferencias según el consume de alcohol y tabaco. International Journal of Clinical and Health Psychology, 8, 483-494.

Moreno-Murcia, J. A., Belando, N., Huéscar, E., \& Torres, M. D. (2017). Social support, physical exercise and life satisfaction in women. Revista Latinoamericana de Psicología, 49, 194-202. https://doi.org/10.1016/j.rlp.2016.08.002

Olefir, V. O., Kuznetsov, M. A., \& Plokhikh, V. V. (2019). Effect of physical exercises and perceived stress interaction on students' satisfaction with life. Pedagogics, Psychology, Medical-Biological Problems of Physical Training and Sports, 23(1), 30-35. https://doi.org/10.15561/18189172.2019.0105

Özkara, A. B., Kalkavan, A., \& Çavdar, S. (2015). Spor bilimleri alanında eğitim alan üniversite ögrencilerinin yaşam doyum düzeylerinin araștırılması. International Journal of Science Culture And Sport, Special Issue 3, 336-346. https://doi.org/10.14486/IJSCS293 
Recepoğlu, E. (2013), Ơğretmen adaylarının yaşam doyumları ile öğretmenlik mesleğine ilişkin tutumları arasındaki ilişkinin incelenmesi, Hacettepe Universitesi Egĭtim Fakuiltesi Dergisi, 1, 311-326.

Roberts, G. C. (2012). Advances in motivation in sport and exercise. E Book Human Kinetics.Com. https://doi.org/10.5040/9781492595182

Schaufeli, W. B., Salanova, M., Gonzales-Roma, V., \& Bakker, A. B. (2002). The measurement of Engagement and burnout: A two sample confirmatory factor analytic approach. Journal of Happiness Studies, 3(1), 71-92. https://doi.org/10.1023/A:101563 0930326

Schmitter, C. (2003). Life satisfaction in centenarians residing in long-term care. Retrieved from http://www.mmhc.com/articles/NHM9912/cutillo.html

Sırganc1, G., Ilgar, E. A., \& Cihan, B. B. (2019). Spora Bağlılık Ölçeğinin Geçerlik ve Güvenirlik Çalışması. Gençlik Araştırmaları Dergisi, 7(17), 5-19.

Sivrikaya, M. H., \& Biricik, Y. S. (2019). Milli Takım Düzeyindeki Elit Kayakçıların Sporcu Bağlılık Düzeylerinin İncelenmesi. 2nd Uluslararası Rekreasyon ve Spor Yönetimi Kongresi.

Siyahtaş, A., Tükenmez, A., Avcı, S., Yalçınkaya, B., \& Çavuşoğlu, S. B. (2020). Bireysel ve takım sporu yapan sporcuların spor bağl1lık düzeylerinin incelenmesi. International Social Mentality and Researcher Thinkers Journal, 6(34), 1310-1317. https://doi.org/ 10.31576/smryj.581

Soyer, F., Can, Y., Güven, H., Hergüner, G., Bayansalduz, M., \& Tetik, B. (2010). Sporculardaki başarı motivasyonu ile takım birlikteliği arasındaki ilişkinin incelenmesi. Uluslararası Insan Bilimleri Dergisi, 7(1), 225-239.

Telef, B. B. (2011). Öğretmenlerin Öz-yeterlikleri, İş Doyumları, Yaşam Doyumları ve Tükenmişliklerinin İncelenmesi. Ilköğretim Online, 10(1) 91-108.

Tunç, A. Cs. (2020). Spor bilimleri fakültesi ögrrencilerinin yaşam doyumu ile mutluluk korkusu düzeylerindeki ilişkinin incelenmesi. Gaziantep Universitesi Spor Bilimleri Dergisi, 5(1), 57-68. https://doi.org/10.31680/gaunjss.655508

Tükenmez, M. (2009). Toplum bilim ve spor. İstanbul: Kaynak Yayınları.

Vara, S. (1999). Yoğun Bakım Hemşirelerinde İs Doyumu Genel Yaşam Doyumu arasında ilişkinin incelenmesi (Ege Üniversitesi Sağlık Bilimleri Enstitüsü, İzmir).

Wang, F., \& Boros, S. (2019). The relationship between physical activity, stress, life satisfaction and sleep quality, Journal of Physical Education and Sport, 19(SP 1), 227-234. https://doi.org/10.7752/jpes.2019.s1034

Willwéber, T. (2016). Effectiveness of the "IAAF kids' athletics project" in levelling changes of general physical performance among boys of early school age. J Phys Educ Health, 5(8), 21-28. 


\section{Macrothink}

Witkowski, K., Piepiora, P. A., Leśnik, M., \& Migasiewicz, J. (2017). Social status of karate and personal benefits declared by adults practicing karate. Arch Budo Sci Martial Art Extreme Sport, 13, 179-184.

Wojdat, M., Rawat, K., Janowska, P., Wolska, B., \& Adam, M. (2017). Comparative analysis of optimism and life satisfaction in Brazilian male and female Ju-Jitsu society. J Educ Health Sport, 7(8), 139-154.

Yamaner, F., Uzunlar, H., \& Efdal, A. (2019). Determination of sport faculty students of the relationship level between commitment to sports and the effects of sport on life skills. Antalya Book of Proceedings 11th International Sport Community Symposium October 28-30, 2019.

Yılmaz, E., \& Aslan, H. (2013). Öğretmenlerin iş yerinde yalnızlıkları ve yaşam doyumları arasındaki ilişkinin incelenmesi. Pegem Ĕ̆itim ve Öğretim Dergisi, 3(3), 5969.

Zullig, K. J., \& White, R. J. (2011). Physical activity, life satisfaction, and self-rated health of middle school students. Applied Research in Quality of Life, 6(3), 277-289. https://doi.org/ $10.1007 / \mathrm{s} 11482-010-9129-\mathrm{z}$

\section{Copyright Disclaimer}

Copyright for this article is retained by the author(s), with first publication rights granted to the journal.

This is an open-access article distributed under the terms and conditions of the Creative Commons Attribution license (http://creativecommons.org/licenses/by/3.0/). 